\title{
Dry matter decomposition and potassium cycling in no-till integrated crop- livestock systems: the effects of tree shading and nitrogen fertilization
}

\author{
Flavia Oliveira ${ }^{1}$, Laíse da Silveira Pontes ${ }^{2 *}$, Tangriani Simioni Assmann ${ }^{3}$, Betina Raquel Cunha dos Santos ${ }^{4}$, \\ Sandoval Carpinelli ${ }^{1}$, Adriel Ferreira da Fonseca ${ }^{1}$
}

\author{
${ }^{1}$ State University of Ponta Grossa, Av. Carlos Cavalcanti, 4748, CEP 84030-900, Ponta Grossa, PR, Brazil \\ ${ }^{2}$ Agronomic Institute of Paraná, Av. Euzébio de Queirós, s/no, CP 129, CEP 84001-970, Ponta Grossa, PR, \\ Brazil \\ ${ }^{3}$ Technological Federal University of Paraná, Via do Conhecimento, km 1, CEP 85503-390, Pato Branco, PR, \\ Brazil \\ ${ }^{4}$ Federal University of Paraíba, Rodovia BR 079 - Km 12, CEP 58397-000, Areia, Brazil
}

*Corresponding author: laisepontes@iapar.br

Abstract

In integrated crop-livestock systems (ICLS), understanding residue dynamics is crucial to synchronize nutrient release from pasture litter to cash-crop nutrient demands and overcome potential deficiencies using suitable fertilization strategies. The present study evaluated how the inclusion of trees and $\mathrm{N}$ availability affected the release rates of $\mathrm{K}$ from pasture (black oat + ryegrass) residues to the subsequent maize crop in a no-till ICLS. The experimental design was randomized blocks with treatments set up in split-plots with three replications. Main plots were systems (crop-livestock only and crop-livestock with trees) and sub-plots $\mathrm{N}$ levels (90 and $180 \mathrm{~kg} \mathrm{~N} \mathrm{ha}^{-1}$ ). Litter decomposition and $\mathrm{K}$ release from pasture residues were assessed using litterbags, which were installed at maize sowing, for retrieval at $8,15,30,60,90,120,150$, and 165 days of incubation. Regardless of $\mathrm{N}$ level, shade of 7-year-old trees reduced pasture residue (-30\%). Tree residues were unable to offset the shading effect on pasture growth. A faster dry matter decomposition was observed in treeless treatment and with $180 \mathrm{~kg} \mathrm{~N} \mathrm{ha}^{-1}$, with a half-life ranging from 14 to 38 days. Despite no changes in K-release dynamics among treatments, total K released was significantly higher for treeless system $\left(61 \mathrm{~kg} \mathrm{~K} \mathrm{ha}{ }^{-1}\right)$ than in system with trees $\left(40 \mathrm{~kg} \mathrm{~K} \mathrm{ha}^{-1}\right)$, due to changes in the initial amount of residue. These results must be taken into account in fertilization practices. Therefore, a few feasible silvicultural interventions should be considered to avoid losses in soil cover, maximizing nutrient cycling benefits.

Keywords: Decomposition; Integrated beef cattle and maize system; Litterbag; Nutrient release; Pasture residue Abbreviations: CL_crop-livestock; CLT_crop-livestock with trees; dbh_diameter at breast height; DM_dry matter; Ht_total height; ICLS_ integrated crop-livestock systems; PAR_Photosynthetically active radiation.

\section{Introduction}

In recent years, integrated crop-livestock systems (ICLS) have gained increasing interest worldwide due to their potential for sustainable intensification, thanks to synergism and emergent properties resulting from soil-plant-animalatmosphere interactions (Moraes et al., 2018). A short-term positive effect of ICLS is nutrient cycling optimization by incorporating pastures and animals into rotation systems with no-till crops (Carvalho et al., 2010; Assmann et al., 2014). For instance, a study showed that large amounts of potassium (130-180 $\mathrm{kg} \mathrm{K} \mathrm{ha}^{-1}$ ) can be cycled in an integrated soybean-beef cattle system, which should be considered in fertilization management practices (Assmann et al., 2017). Currently, the incorporation of trees into farming systems has been proposed to maximize biodiversity, as an effort to improve global food and nutritional security. There are 30 million farms under this subtype of sustainable intensification (Pretty, 2018). In no-till ICLS, tree integration may contribute to nutrient cycling by absorbing nutrients from deep layers and releasing them into the topsoil. Furthermore, the tree component of ICLS may affect decomposition either directly through litter quality or mass, or indirectly through microclimate or decomposer communities (Guo and Sims, 2001; Menezes et al., 2002; Aerts, 2006). For instance, understory grasses exhibit alterations in anatomy and physiology to compensate for low light quantity and distinct quality (Cavagnaro and Trione, 2007), with impacts on production and nutritive value (Pontes et al., 2016). However, differential responses to shading are observed across studies (e.g. positive and negative effects of shading in nutritive value, Samarakoon et al., 1990; Abraham et al., 2014), which can be explained in part by differences in the nitrogen $(\mathrm{N})$ availability (Pontes et 
al., 2016). These inconsistent responses lead to differences in the quantity and quality of the pasture litter and consequently alter decomposition and nutrient-cycling dynamics. Furthermore, a large range of instantaneous decay constants ( $k$-value) has been reported for some tree species e.g., eucalypt (Guo and Sims, 2001). The higher the $k$-value causes faster litter decomposition. This might be due to light condition and tree age or density. As a consequence, variations in the components of ICLS, i.e. in the different soiltree-herbaceous combinations, might play some important roles in the nutrient cycling. Thus, there is a need to understand the impacts of interactive shade and $\mathrm{N}$ availability on nutrient cycling to design sustainable ICLS with trees. However, current knowledge of ICLS with trees on a variety of agricultural sustainability issues, one of which is on nutrient cycling, is still limited in tropical and subtropical conditions. By understanding these factors, ICLS managers could better synchronize nutrient release with nutrient demand in subsequent crops, ensuring a more efficient use of nutrients.

We hypothesized that, in a typical ICLS of southern Brazil (summer cash-crop and cattle grazing rotations), decomposition rate and nutrient release from cool-season annual forages could be affected by alterations in the structure and quality of residues derived from $\mathrm{N}$ availability and association with trees. In addition, increases in $\mathrm{N}$ availability and tree residues may offset likely losses in pasture residue production, when comparing a system with 7-year-old trees and another without trees.

In this context, the objective of this research was to quantify dry matter (DM) decomposition and nutrient release (particularly K, one of the most commonly required nutrients in tropical and subtropical agriculture) from residues of stocking season in two ICLS (with and without trees) and two $\mathrm{N}$ fertilization levels.

\section{Results and discussion}

\section{Effects of trees and nitrogen supply on dry matter residue and $K$ concentration}

We observed significantly higher DM residue value (Table 1 ), at the end of the stocking season, in CL $(4605 \pm 442.5 \mathrm{~kg}$ DM $\left.\mathrm{ha}^{-1}\right)$ compared to $\mathrm{CLT}\left(3230 \pm 129.2 \mathrm{~kg} \mathrm{DM} \mathrm{ha}^{-1}\right)$ systems regardless of $\mathrm{N}$ level. This result indicated that shade provided by the 7-year-old trees in the CLT - as high as $41 \pm$ $2.41 \%$ in relation to the open field - affected pasture growth $(-30 \%)$. Pontes et al. (2017) have already shown that, regardless of sward height, CLT systems produce less DM (in a black oat + ryegrass pasture mixture) than a $\mathrm{CL}$ system, under a high shading level (>50\%). A reduction in tiller density is one of the main causes of lower herbage production in shaded areas (Pontes et al., 2017).

The input of residues from trees was unable to offset the shading effect on pasture growth. Actually, $47.7 \pm 5.22 \%$ of the residue in CLT was composed of materials from trees, with no differences between both $\mathrm{N}$ levels $(F=1.02, \mathrm{p}>0.10)$ and among tree-row distances $(F=2.18, p>0.10)$, which is due to a high coefficient of variation (46.5\%). Moreover, the results of initial $\mathrm{K}$ concentration showed no significant differences for treatments with a mean of $13 \pm 0.78 \mathrm{~g} \mathrm{~kg}^{-1}$ (Table 1). Effects of trees and nitrogen supply on dry matter
decomposition of black oat and ryegrass mixture

The active fraction of DM that decomposed varied significantly among $\mathrm{N}$ levels, while the non-linear decay constant of the active fraction $(k)$ varied significantly with systems and $\mathrm{N}$ levels (Table 1 ). Therefore, the final exponential models were fitted to DM decomposition for each $\mathrm{N}$ level and each system (Fig. 1). A greater active fraction and a faster $\mathrm{DM}$ decomposition were observed in $\mathrm{CL}$ (e.g., 61\% of the DM was decomposed within 165 days), when compared to the CLT (Fig. 1), probably due to differences in plant species (e.g., pasture vs. tree residues) and environmental conditions between the systems (e.g. temperature, Guo and Sims, 2001, Menezes et al., 2002). In addition, decomposition of pasture residue was accelerated with increasing $\mathrm{N}$ supply (e.g. $56 \%$ of the DM was decomposed within 165 days in N180 treatments vs. $46 \%$ in N90 treatments, Fig. 1). This effect was particularly isolated in the size of fraction active (i.e. pasture residue was mainly in the labile fraction, $59 \%$, in N180 treatments), but not in the rate of decomposition, as also observed by Assmann et al. (2014), with dual-purpose wheat, when increasing number of grazing days. According to Knorr et al. (2005), high quality (low lignin) litter responds more to $\mathrm{N}$, i.e. litter decomposition is stimulated by $\mathrm{N}$ addition. Further, the number of days needed to decompose $50 \%$ of the initial residue ranged from 14 (N90) to 38 (N180) days (Fig. 1). These half-life results were faster when compared with other studies with grass species (e.g. Assmann et al., 2014). Differences in environmental conditions and nutrients supply, as $\mathrm{N}$ fertilization, via litter quality and decomposers effects, can explain these differences in results between sites (Knorr et al., 2005; Aerts, 2006; Henry and Moise, 2014).

\section{Potassium released from stocking season residues into the} maize growing season

The active fraction of $K$ that released and its non-linear decay constant had no significant ( $p>0.10$ ) effect between systems and $\mathrm{N}$ levels (Table 1), averaging $96 \%$ (or $96 \mathrm{~g} \mathrm{~K} \mathrm{~kg}^{-1}$ residue) and $4.9 \mathrm{mg} \mathrm{g}^{-1} \mathrm{day}^{-1}$ (or $0.049 \mathrm{day}^{-1}$ ), respectively. As a consequence, the number of days needed to release $50 \%$ of the $\mathrm{K}$ was 14 on average. At the end of incubation period, only about $3.6 \%$ of the initial $\mathrm{K}$ content remained in litterbags (Fig. 1). Such a rapid release of $K$ into the soil (above $70 \%$ within a month, Fig. 1) has already been reported in other studies (Assmann et al., 2014; Assmann et al., 2017). As $\mathrm{K}$ plays a minor role in organic compounds (Marschner, 1995), its cycle tends to be shorter and faster. Therefore, to speed up $\mathrm{K}$ release from pasture residues, cash crop should be planted immediately after cover crop management, which in turn has to be made soon after animals had left the area to avoid $\mathrm{K}$ leaching through soil profile (Assmann et al., 2014).

Despite no-significant differences in the active fraction of $K$ that released and its non-linear decay constant, the total $K$ released was fitted to each system (Fig. 2) due significant differences in initial mass of residue (Table 1). Consequently, 
Table 1. Summary of the variance analyses ( $F$-ratio and probability) for initial dry matter (DM) and potassium (K) concentration of residues in stocking season, the active fraction $(a c t)$ and the non-linear decay constant of the active fraction $(k)$ of $D M$ and $K$ in relation to systems $(\mathrm{S})$, nitrogen rates $(\mathrm{N})$ and interaction.

\begin{tabular}{lccc}
\hline Source of variation & $\mathrm{S}$ & $\mathrm{N}$ & $\mathrm{S} \times \mathrm{N}$ \\
\hline $\mathrm{Df}$ & 1 & 1 & 1 \\
$\mathrm{DM}$ & $5.8^{*}$ & $0.33 \mathrm{~ns}$ & $-\mathrm{ns}$ \\
$\mathrm{K}$ & $0.64 \mathrm{~ns}$ & $0.90 \mathrm{~ns}$ & $-\mathrm{ns}$ \\
$\operatorname{act}(\mathrm{DM})$ & $0.76 \mathrm{~ns}$ & $8.51^{* *}$ & $-\mathrm{ns}$ \\
$k(\mathrm{DM})$ & $4.96^{*}$ & $8.72^{* *}$ & $-\mathrm{ns}$ \\
$\operatorname{act}(\mathrm{K})$ & $1.25 \mathrm{~ns}$ & $2.69 \mathrm{~ns}$ & $-\mathrm{ns}$ \\
$k(\mathrm{~K})$ & $0.52 \mathrm{~ns}$ & $0.04 \mathrm{~ns}$ & $-\mathrm{ns}$ \\
\hline at: ${ }^{*} \mathrm{p}=0.1$ level; ** $\mathrm{p}=0.05$ level; ns: not significant; Df: Degrees of freedom; -ns: Non-significant interactions were removed from the final model.
\end{tabular}
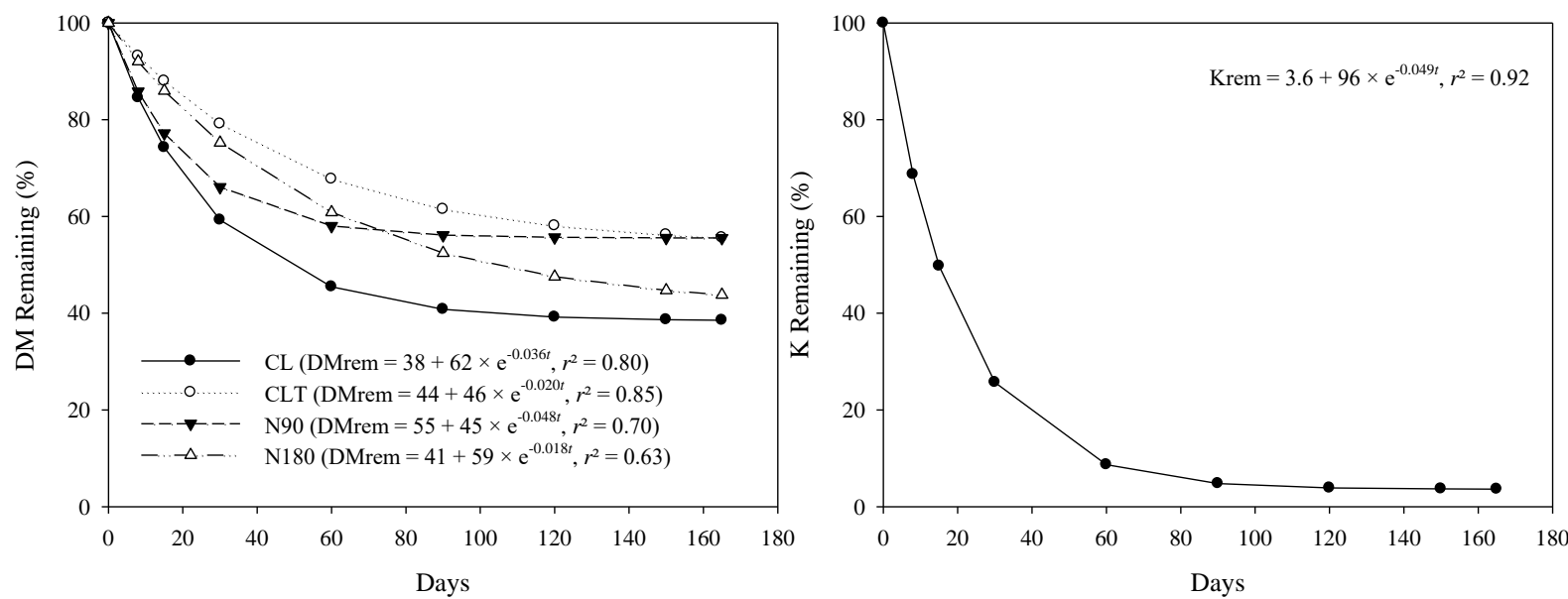

Fig 1. Remaining (rem) dry matter (DM) and potassium (K) from stocking season [i.e., from pasture residues (Lolium multiflorum + Avena strigosa) or from pasture + tree residues] after litterbag exposure in the field as affected by treatments (crop-livestock $-\mathrm{CL}$, and crop-livestock-tree -CLT systems; at 90 and $180 \mathrm{~kg} \mathrm{~N}$ ha $^{-1}-\mathrm{N} 90$ and N180, respectively). Remaining DM or $\mathrm{K}(\mathrm{rem})=$ res + act $x$ $\mathrm{e}^{-k t}$. res, resistant fraction; act, active fraction; $k$, non-linear decay rate; $r^{2}$, coefficient of determination.

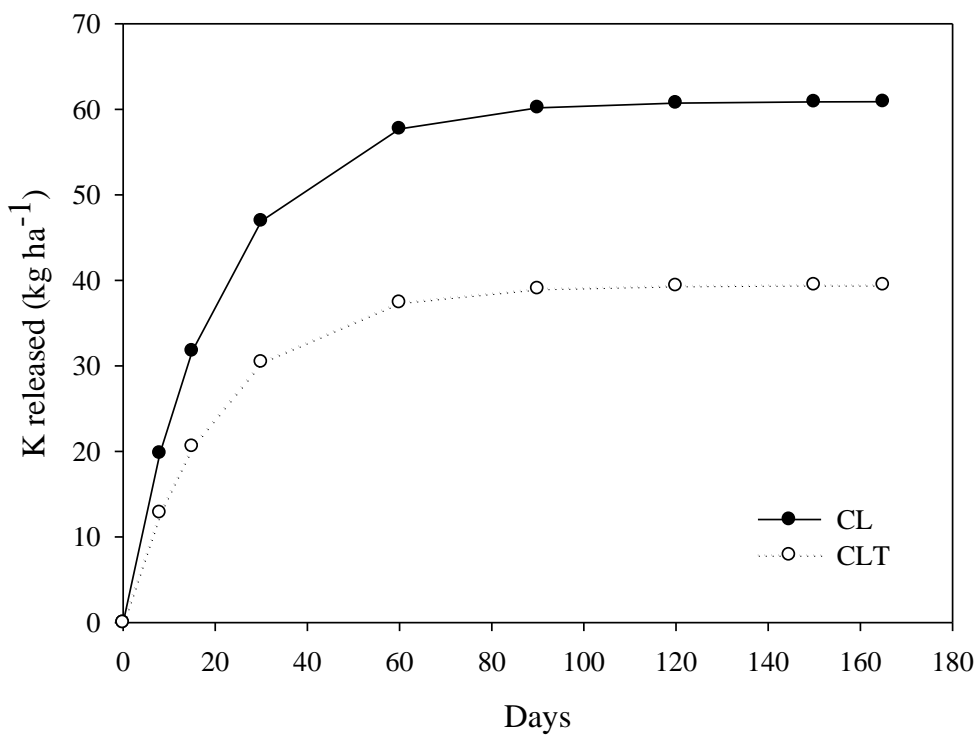

Fig 2. Potassium (K) released from stocking season residues [i.e., from pasture residues (Lolium multiflorum + Avena strigosa) or from pasture + tree residues] after litterbag exposure into the maize growing season as affected by systems. See Figure 1 for systems codes. 
the total $\mathrm{K}$ released from residue during stocking season to maize crop was higher for $\mathrm{CL}-60.9 \mathrm{~kg} \mathrm{~K} \mathrm{ha}^{-1}$ than CLT - 39.5 $\mathrm{kg} \mathrm{K} \mathrm{ha}^{-1}$ (Fig. 2). Despite the input of about $1500 \mathrm{~kg} \mathrm{DM} \mathrm{ha}^{-1}$ from residues of trees, the $K$ content released in CLT was $35 \%$ lower than that of CL. In fact, Ludvichak et al. (2016) reported a K return to the soil of only $23.4 \mathrm{~kg} \mathrm{ha}^{-1}$ from 6995 $\mathrm{kg} \mathrm{DM} \mathrm{ha} a^{-1}$ of $E$. dunnii residues. A poorer DM residue from pasture in CLT emphasizes the need for more intensive management of the tree component, for instance by reducing tree density through either thinning or removing tree rows from the system. Maize grain yield was $2899 \mathrm{~kg}$ ha ${ }^{1}$ and $6158 \mathrm{~kg} \mathrm{ha}^{-1}$ for CLT and CL, respectively (see Pontes et al., 2018a). As K extraction by maize is $17.1 \mathrm{~kg} \mathrm{~K} \mathrm{t}^{-1}$ grain (SBCS/NEPAR, 2017), the estimates for these yield levels were 106 and $50 \mathrm{~kg} \mathrm{~K}$ for CL and CLT, respectively. Thereby, on average, $\mathrm{K}$ cycling had a contribution of 57 and $79 \%$ to $\mathrm{K}$ extraction by maize crops for $\mathrm{CL}$ and $\mathrm{CLT}$, respectively. Besides that, the amount of $\mathrm{K}$ cycled was enough to restore the exported contents. For instance, nearly $5.4 \mathrm{~kg} \mathrm{~K}$ was exported through grains (SBCS/NEPAR, 2017). Considering the amount of $K$ released by pasture decomposition, $K$ fertilization in no-till systems should be reduced, avoiding excesses and hence $\mathrm{K}$ leaching, particularly in sandy soils. It is also important to consider animal excreta as another $\mathrm{K}$ source (Assmann et al., 2017), of which urine has a greater contribution (Haynes and Williams, 1993) for its ready availability to plants, thus increasing $\mathrm{K}$ in ICLS farming. Briefly, our results reinforce the need to understand nutrient release patterns from residues (animal and plant) in the long-term for ICLS conditions to improve fertilization management.

\section{Materials and Methods}

\section{Study area}

A field experiment was conducted at Agronomic Institute of Paraná, Ponta Grossa-PR (2507'22" S, 5003'01' W), southern Brazil. The local climate is humid subtropical, or $\mathrm{Cfb}$ in the Köppen classification system, which is characterized by frequent frosts and mean annual

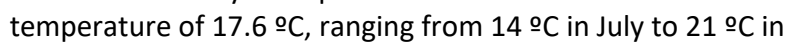
January. The mean annual rainfall is $1400 \mathrm{~mm}$. The soil is a Cambisol and Ferralsol (Embrapa, 2006) with 19\%, 3\%, and $78 \%$ clay, silt, and sand in the upper $20 \mathrm{~cm}$, respectively.

\section{Treatments and the experimental design}

The experimental design was randomized blocks with treatments set up in split-plots with three replications, whose factors included two doses of $\mathrm{N}$ fertilization (90 and $180 \mathrm{~kg} \mathrm{~N} \mathrm{ha}^{-1}$, named $\mathrm{N} 90$ and N180, respectively) and ICLS (which implied, with and without trees, named $\mathrm{CLT}$ and $\mathrm{CL}$, respectively, i.e. crop-livestock with trees and crop-livestock only). The main plots consisted of systems (i.e. two types of ICLS) and the sub-plots were $\mathrm{N}$ levels. The experimental area of 13.07 ha was divided into 12 plots ranging from 0.77 to 1.22 ha. Please refer to Pontes et al. (2018b) for further information on experimental site.

\section{Conduction of study}

In 2006, three tree species (eucalyptus, Eucalyptus dunnii; pink pepper, Schinus molle; and silver oak, Grevillea robusta) were planted in 6 out of 12 plots (i.e. experimental units). The tree species were interspersed within rows crosswise the slope decline with a $3 \times 14 \mathrm{~m}$ spacing $\left(238\right.$ trees $\mathrm{ha}^{-1}$ ). Since 2006, the experimental area was maintained under notillage cropping conditions. An ICLS was established in 2010, in all the 12 plots, consisting of black oat (Avena strigosa) + ryegrass (Lolium multiflorum) grazed with beef-cattle (Purunã beef heifers) during winter and maize or soybean cropping during summer. The experimental units were managed in order to maintain a target surface sward height of $20 \mathrm{~cm}$ by adjusting the number of grazing animals weekly, i.e. using a put-and-take grazing method. During the summer of 2013 , tree density was reduced in $1 / 3$ (158 trees ha ${ }^{-1}$ ) by removing pink pepper trees, many of which had been damaged by cattle browsing.

The current study was performed between 2013 and 2014 . The black oat + ryegrass mixture was sown in April 2013 at a seed rate of 45 and $15 \mathrm{~kg} \mathrm{ha}^{-1}$, respectively, subsequently fertilized with $400 \mathrm{~kg} \mathrm{ha}^{-1}$ of NPK commercial formula (4-3010). Urea was applied approximately 40 days after the pasture was sown, using $90 \mathrm{~kg} \mathrm{~N} \mathrm{ha}^{-1}$ or $180 \mathrm{~kg} \mathrm{~N} \mathrm{ha}^{-1}$, resulting in the evaluation of two $\mathrm{N}$ fertilization rates, as cited above. Maize (variety IPR 164) was sown in November 2013 (75,000 plants ha ${ }^{-1}$; with 80-cm row spacing), fertilized with $400 \mathrm{~kg} \mathrm{ha}^{-1}$ of NPK commercial formula (10-30-10). Topdressing was performed 40 days after sowing, using a single dose of $270 \mathrm{~kg} \mathrm{ha}^{-1}$ urea in both ICLS.

\section{Plant material and measurements of decomposition and potassium release rates}

Potassium cycling was evaluated from November 2013 to April 2014 and consisted of assessing decomposition rates of residue from pasture in $\mathrm{CL}$ system, and from pasture + tree $\mathrm{DM}$ in $\mathrm{CLT}$ system, and $\mathrm{K}$ release rates during maize cropping cycle. Plant shoot residues (pasture - tree) were collected at the end of stocking season in nine and twelve representative areas $\left(0.25 \mathrm{~m}^{2}\right)$ for $\mathrm{CL}$ and $\mathrm{CLT}$, respectively. To better characterize the CLT system, four samples were collected at three distances from tree rows, i.e., 1.75, 3.5, and $7 \mathrm{~m}$ apart (see Pontes et al. 2018a for more details). Dry matter decomposition was evaluated in succeeding maize crop, using litterbags placed on the soil surface. Residue samples of $20 \mathrm{~g}$ were placed into $20 \times 20 \mathrm{~cm}$ nylon-screen litterbags with $2 \mathrm{~mm}$ openings. A total of it's $3 \times$ the numer of dates, so the total is 24 litterbags were placed in each experimental unit during maize sowing, for retrieval at $8,15,30,60,90$, 120,150 , and 165 days of incubation. Litterbag contents were oven-dried $\left(55^{\circ} \mathrm{C}\right.$ ) and weighed to determine $\mathrm{DM}$ decomposition and $\mathrm{K}$ release from weight differences and $\mathrm{K}$ concentration among incubation periods. Litter samples were ground in a Wiley mill with a 1-mm mesh screen for laboratory analysis. Total $\mathrm{K}$ was analyzed by flame photometry (Malavolta et al., 1997).

\section{Tree characteristics and shading percentage}

During maize cultivation, eucalyptus trees showed an average of $32.5 \mathrm{~cm}$ in $\mathrm{dbh}$ (diameter at breast height) and 
$19.4 \mathrm{~m}$ in total height $(\mathrm{Ht})$, while silver oak had $17.1 \mathrm{~cm} \mathrm{dbh}$ and $11.4 \mathrm{~m} \mathrm{Ht}$. The degree of light reduction under tree canopies was compared to that of the treeless system in September 2013, with the aid of two ceptometers (AccuPAR LP-80, Decagon Devices, Pullman, WA, USA). One of which was positioned under full sunlight, and the other under tree canopies. Photosynthetically active radiation (PAR) measurements were made every $30 \mathrm{~min}$, between 9:00 and 15:00 $\mathrm{h}$. The percentage of change in PAR was calculated from the difference between the two values recorded by both ceptometers.

\section{Statistical analyses}

Data of DM and remaining $\mathrm{K}$ from each retrieval event were fitted to a nonlinear model for each experimental unit or tree-row distance, to establish decomposition characteristics for further analysis of variance (ANOVA). The exponential model used was:

rem $=r e s+a c t \times e^{-k t}$

Wherein: rem is remaining constituent (DM and $\mathrm{K}$ ) after $t$ (days), res is the size of a resistant fraction showing no decomposition signs during 165 days, act is the size of active fraction decomposing during 165 days, and $k$ is the nonlinear decay constant of the active fraction. The residue halflife, namely the time for $50 \%$ DM decomposition of $\mathrm{K}$ release, was calculated using the following formula (Paul and Clark, 1996):

$t^{1 / 2}=0.693 / k$

In a first ANOVA, possible differences were verified between the three distances (i.e. 1.75, 3.5, and $7 \mathrm{~m}$ ) from the tree rows in the CLT system. Because there were no significant differences $(p>0.10)$, data corresponding to the CLT were the mean of all three distances. Analyses of variance were then performed for total DM residue, initial K concentration, and act and $k$ using split-plot-like model in Statgraphics Centurion XV software (2006). Main plots were the systems $(D F=1)$ and subplots were $N$ levels $(D F=1)$. All factors except blocks were considered as fixed terms. The error term for systems was block (system). Interaction $\mathrm{N} \times$ system was checked for each variable and removed from the model if it had a $p$ value $>0.10$. According to ANOVA, for act and $k$, exponential models were redone to simplify the results. During the evaluation period, the cumulative $\mathrm{K}$ release was estimated by multiplying the rate of $\mathrm{K}$ released by the initial quantity available in the residue.

\section{Conclusions}

After 165 days of plant material decomposition, significant amounts of $\mathrm{K}\left(61 \mathrm{~kg} \mathrm{ha}^{-1}\right)$ were cycled under a beef-cattle and maize integration system, which must be considered for fertilization management practices. Contrary to our hypothesis, neither an increase in nitrogen availability nor an input of residue from trees was enough to offset the amount of pasture residue lost under trees. Thus, silvicultural interventions need to be intensified to reduce shading to less than $41 \%$ and avoid losses of soil cover, which in turn will enhance benefits from nutrient cycling.

\section{Acknowledgments}

The authors extend their gratitude to Giliardi Stafin for technical support and Dra. Carolina Bremm for valuable statistics comments. This study was performed as part of a cooperation agreement (No. 21500.10/ 0008-2) between IAPAR and Embrapa Forestry. The second author is grateful to CNPq for the fellowship granted (305803/ 2018-2).

\section{References}

Abraham EM, Kyriazopoulos AP, Parissi ZM, Kostopoulou P, Karatassiou M, Anjalanidou K, Katsouta C (2014) Growth, dry matter production, phenotypic plasticity, and nutritive value of three natural populations of Dactylis glomerata L. under various shading treatments. Agroforest Syst. 88:287-299.

Aerts R (2006) The freezer defrosting: global warming and litter decomposition rates in cold biomes. J Ecol. 94:713724.

Assmann TS, Bortolli MA de, Assmann AL, Soares AB, Pitta CSR, Franzluebbers AJ, Glienke CL, Assmann JM (2014) Does cattle grazing of dual-purpose wheat accelerate the rate of stubble decomposition and nutrients released? Agr Ecosyst Environ. 190: 37-42.

Assmann JM, Martins AP, Anghinoni I, Denardin LG de O, Nichel $\mathrm{G}$ de $\mathrm{H}$, Costa SE VG de Andrade, Silva RAP e, Balerini F, Carvalho PC de F, Franzluebbers AJ (2017) Phosphorus and potassium cycling in a long-term no-till integrated soybean-beef cattle production system under different grazing intensities in subtropics. Nutr $\mathrm{Cycl}$ Agroecosys. 108:21-33.

Carvalho PC de F, Anghinoni I, Moraes A de, Souza ED de, Sulc RM, Lang CR, Flores JPC, Lopes MLT, Silva JLS da, Conte $\mathrm{O}$, Wesp C de L, Levien R, Fontaneli RS, Bayer C (2010) Managing grazing animals to achieve nutrient cycling and soil improvement in no-till integrated systems. Nutr Cycl Agroecosys. 88: 259-273.

Cavagnaro JB, Trione SO (2007) Physiological, morphological and biochemical responses to shade of Trichloris crinita, a forage grass from the arid zone of Argentina. J Arid Environ. 68:337-347.

Embrapa, Empresa Brasileira de Pesquisa Agropecuária (2006) Centro Nacional de Pesquisa de Solos. Sistema brasileiro de classificação de solos. 2nd edn. Embrapa Produção de Informação, Rio de Janeiro. 306.

Guo LB, Sims REH (2001) Effects of light, temperature, water and meatworks effluent irrigation on eucalypt leaf litter decomposition under controlled environmental conditions. Appl Soil Ecol. 17: 229-237.

Haynes RJ, Williams PH (1993) Nutrient cycling and soil fertility in the grazed pasture system. Adv Agron. 49:119199.

Henry HAL, Moise ERD (2014) Grass litter responses to warming and $\mathrm{N}$ addition: temporal variation in the contributions of litter quality and environmental effects to decomposition. Plant Soil. 389:35-43.

Knorr M, Frey SD, Curtis PS (2005) Nitrogen additions and litter decomposition: a meta-analysis. Ecology. 86:32523257.

Ludvichak AA, Schumacher MV, Dick G, Momolli DR, Souza HP de, Guimarães C do C (2016) Nutrient return through litterfall in a Eucalyptus dunnii Maiden stand in sandy soil. Rev Árvore. 40:1041-1048. 
Malavolta E, Vitti GC, Oliveira SA (1997) Avaliação do estado nutricional das plantas: princípios e aplicações. Potafos, Piracicaba. 319.

Marschner H (1995) Mineral Nutrition of Higher Plants. Academic Press, San Diego. 889.

Menezes RSC, Salcedo IH, Elliott ET (2002) Microclimate and nutrient dynamics in a silvopastoral system of semiarid northeastern Brazil. Agroforest Syst. 56:27-38.

Moraes A, Carvalho PC de F, Crusciol CAC, Lang CR, Pariz CM, Deiss L, Sulc RM (2018) Integrated Crop-Livestock Systems as a Solution Facing the Destruction of Pampa and Cerrado Biomes in South America by Intensive Monoculture Systems. In: Lemaire G, Carvalho PC de F, Kronberg S, Recous $S$ (eds) Agroecosystem Diversity: Reconciling Contemporary Agriculture and Environmental Quality. Academic Press, eBook. 257.

Paul EA, Clark FE (1996) Soil microbiology and biochemistry. 2nd edn. Academic Press, California. 340.

Pontes L da S, Giostri AF, Baldissera TC, Barro RS, Stafin G, Porfírio-da-Silva V, Moletta JL, Carvalho PC de F (2016) Interactive Effects of Trees and Nitrogen Supply on the Agronomic Characteristics of Warm-Climate Grasses. Agron J. 108:1531-1541.

Pontes L da S, Carpinelli S, Stafin G, Porfírio-da-Silva V, Santos BRC dos (2017) Relationship between sward height and herbage mass for integrated crop-livestock systems with trees. Grassl Sci. 63:29-35.

Pontes L da S, Tullio GF, Martins A de S, Moletta JL, Porfírioda-Silva V (2018a) Corn yield for silage and grains in different integrated crop-livestock systems. Rev Cienc Agron. 49: 315-323.

Pontes L da S, Barro RS, Savian JV, Berndt A, Moletta JL, Porfirio-Da-Silva V, Bayer C, Carvalho PC de F (2018b) Performance and methane emissions by beef heifer grazing in temperate pastures and in integrated croplivestock systems: The effect of shade and nitrogen fertilization. Agr Ecosyst Environ. 253:90-97.

Pretty J (2018) Intensification for redesigned and sustainable agricultural systems. Science. 362:eaav0294.

Samarakoon SP, Wilson JR, Shelton HM (1990) Growth, morphology and nutritive value of shaded Stenotaphrum secundatum, Axonopus compressus and Pennisetum clandestinum. J Agr Sci. 114:161-169.

Sociedade Brasileira de Ciência do Solo. Núcleo Estadual Paraná - SBCS/NEPAR (2017) Manual de adubação e calagem para o Estado do Paraná. SBCS/NEPAR, Curitiba. 482. 